\title{
Gênero, feminismo e geração: uma análise dos perfis e opiniões das mulheres manifestantes no Rio de Janeiro*
}

\author{
Veronica Toste Daflon** \\ Débora Thomé Costa*** \\ Felipe Borba ${ }^{* * * *}$
}

\begin{abstract}
Resumo
O artigo aborda perfis e opiniões de mulheres presentes na manifestação do 8 de Março de 2017 no Rio de Janeiro, sondados através de uma pesquisa de survey. A análise dos dados revelou que as variáveis cor, renda, escolaridade e orientação sexual não afetaram significativamente a opinião das entrevistadas. O que se mostrou relevante foram as diferenças por idade. Os dados apontaram também transformações na composição racial, etária e socioeconômica das feministas. A partir desses achados, investigamos a relação entre gênero, feminismo e geração no que toca estratégias e repertórios de mobilização, identidade, gênero, corpo, subjetividade, sexualidade, cultura e política.
\end{abstract}

Palavras-Chave: Movimentos Sociais, Feminismo, Gênero, Gerações, Protesto.

\footnotetext{
* Recebido em 30 de abril de 2018, aceito 26 de junho de 2020. Esta pesquisa contou com recursos da FAPERJ Fundação Carlos Chagas Filho de Amparo à Pesquisa do Estado do Rio de Janeiro.

** Professora Adjunta do Departamento de Sociologia e Metodologia em Ciências Sociais e do Programa de PósGraduação em Sociologia (PPGS), da Universidade Federal Fluminense (UFF), Niterói, RJ, Brasil. veronicatoste@id.uff.br.com/ https://orcid.org/0000-0001-8398-2131

*** Doutora em Ciência Política no Programa de Pós-Graduação em Ciência Política da Universidade Federal Fluminense (PPGCP/UFF), Niterói, RJ, Brasil. debora.thome@gmail.com / https://orcid.org/0000-0002-1071-6980

**** Professor Adjunto da Escola de Ciência Política da Universidade Federal do Estado do Rio de Janeiro (CCJP/UNIRIO), Rio de Janeiro, RJ, Brasil. felipe.borba10@gmail.com / https://orcid.org/0000-0001-8396-7548 
Gender, Feminism and Generations: An Analysis of the Profiles and Opinions of Women Demonstrators in Rio De Janeiro"

\begin{abstract}
This paper examines the opinions and profiles of women protesters at the International Women's Day demonstration on 8 March 2017 in Rio de Janeiro as revealed by an opinion poll. The data analysis shows that the variables skin color, income, education and sexual orientation do not significantly affect the opinions of the interviewees. What is relevant are the age differences. The data also show changes in the racial, age and socioeconomic profiles of the feminist protesters. Based on these findings, we investigate the relationship between gender, feminism and generation in terms of identity, gender, body, subjectivity, sexuality, culture, politics and strategies and repertoires for mobilization.
\end{abstract}

Keywords: Social Movements, Feminism, Gender, Generations, Protest. 


\section{Introdução}

Em 2017, a manifestação do 8 de Março atraiu em torno de 15 mil pessoas ao centro da cidade do Rio de Janeiro (O Estado de S. Paulo, 2017). Na ocasião, reunimos uma equipe de pesquisadoras para aplicar questionários entre as participantes, selecionando-as de acordo com uma metodologia desenvolvida especificamente para protestos de rua. Ao garantir a aleatoriedade da seleção das entrevistadas, esse método - denominado survey de protesto - nos permitiu conhecer o perfil, as atitudes e as opiniões de uma amostra representativa do total de participantes. O questionário trazia perguntas sobre características sociodemográficas, fontes de informação $e$ mobilização, filiações político-partidárias, repertórios, formas de atividade política e opiniões a respeito de algumas questões-chave para o feminismo atual.

Após a análise da relação estatística entre os perfis sociodemográficos e as opiniões das entrevistadas, constatamos que variáveis como cor, renda, escolaridade e orientação sexual não afetavam significativamente as opiniões. O que se mostrou relevante foram as diferenças por idade: as participantes mais jovens e mais velhas divergiram em diversos aspectos. Essa tendência está em linha com várias pesquisas qualitativas recentes, que apontam para diferenças "geracionais" no interior do campo feminista (Adrião e Mello, 2009; Branco, 2015; Gonçalves e Pinto, 2011; Gomes e Sorj, 2014; Name e Zanetti, 2013; Sorj, 2016; Buarque de Hollanda, 2018; Gonçalves, 2016).

Com apoio dos dados obtidos no survey, o artigo dialoga com essa literatura, comparando os perfis das militantes no que toca a sua visão sobre identidade, gênero, corpo, subjetividade, sexualidade, cultura, política, desigualdades, estratégias e repertórios de mobilização. O texto se organiza da seguinte forma: primeiro, revisitamos a bibliografia sobre a relação entre gênero, feminismo e geração no Brasil para, em seguida, apresentar o campo em que a pesquisa foi realizada. Em sequência, apresentamos a metodologia da pesquisa. Por fim, dialogamos com a literatura a partir dos resultados do survey, buscando um nível de generalização maior do que costumam permitir os estudos qualitativos disponíveis até o momento.

A principal contribuição do trabalho está relacionada à coleta de dados e à estatística descritiva. Há hoje na literatura uma lacuna com respeito à pesquisa do perfil e opiniões das feministas, sendo ainda mais rara a aplicação de métodos quantitativos, como os surveys. O tema costuma ser tratado a partir de uma leitura observativo-participativa do(a) pesquisador(a) em grupos restritos de observação. Reconhecemos que a dimensão interpretativa desses estudos é fundamental para a compreensão do fenômeno. O texto que se segue, porém, procura abrir espaço para reflexões a partir de um número maior de observações do grupo.

\section{Feminismos em fluxo}

Sonia Alvarez (2014) propõe um entendimento dos feminismos latino-americanos como um campo complexo e em fluxo permanente e afirma que o feminismo no Brasil já nasceu plural e heterogêneo. Para fins expositivos, no entanto, faremos um breve exercício de simplificação, que retrocede aos anos 1970. Escrever a história de qualquer movimento social é uma tarefa árdua. Isso porque os enredos e as narrativas históricas são, eles mesmos, parte das identidades coletivas, das reivindicações de legitimidade, dos processos de inclusão e exclusão e da retórica política dos próprios movimentos (Jasper, 2014).

Na década de 1970, a conjuntura política do país impunha aos movimentos sociais a resistência à ditadura, em ações que ocorriam fora da institucionalidade estatal (Sanchez, 2017). Por esse motivo, a atividade feminista no período se realizou no âmbito da sociedade civil; fosse de forma "autônoma", fosse dentro de organizações de esquerda. O slogan "o pessoal é político" marca as narrativas sobre o período, projetando a necessidade de se levar à esfera pública questões então encaradas como de ordem privada: a violência doméstica, o aborto, a conciliação entre família e mercado de trabalho, entre outras. Iniciado o período de redemocratização do país, as feministas foram extremamente ativas na Campanha da Anistia e articularam o "Lobby do Batom", tomando parte na mobilização e disputas em torno da redação da nova Constituição Federal $e$ garantindo a inclusão de uma série de marcos legais em prol da igualdade de gênero (Melo; Thomé, 2018). 
Ao longo dos anos 1990, diversas feministas passaram a exercer funções na burocracia estatal, circulando entre movimentos sociais e Estado, e constituindo ONGs especializadas e profissionalizadas (Sanchez, 2017). Data também desse período a incorporação da transversalização de gênero nos marcos conceituais e normativos da proteção internacional aos Direitos Humanos (García Muñoz, 2010), o que abriu oportunidades para inúmeras feministas tomarem parte em uma estrutura densa, triangular, entre Estados, atores não-estatais e instituições internacionais.

Nos anos 2000, a institucionalização e a burocratização do feminismo passaram a ser alvos de forte contestação. Feministas autodenominadas "autônomas" criticavam as "institucionais", acusadas frequentemente de capitulação com o neoliberalismo e com o patriarcalismo global (Alvarez, 2014). O discurso da "autonomia" - contraposto ao da "institucionalidade" - marcou disputas políticas que iriam desembocar na multiplicação dos campos feministas para além do Estado e das ONGs e na disseminação de práticas de feminismos plurais para vários setores da sociedade civil. Esse tipo de atividade foi legado de construções que já datavam da última década, mas, entre as agentes desses processos, figuraram também feministas que se autointitulavam "jovens" (Alvarez, 2014).

Nos anos 2000, "jovens feministas" passaram a reivindicar voz, presença e questionar assimetrias de poder em diversos espaços feministas constituídos (Gonçalves e Pinto, 2011). Em encontros nacionais feministas de 2005 e 2006, por exemplo, elas se queixavam da falta de espaços para construção autônoma, da falta de legitimação de suas falas e de serem preteridas na liderança pelas "feministas históricas" (Adrião e Mello, 2009). "Geração" se tornava um marcador cada vez mais relevante, ou mesmo uma marca de identidade no interior de vários movimentos (Gonçalves e Pinto, 2011).

Muitas das que se reconheciam como "jovens feministas" começaram a se organizar ainda na década de 2000 (Adrião e Mello, 2009), mas foi na década de 2010 que elas ganharam mais visibilidade. A apropriação das plataformas de comunicação digital, a formação de coletivos em universidades públicas e privadas e escolas de nível médio se tornaram algumas das expressões mais visíveis de uma nova fase do feminismo brasileiro, em que as "jovens", agora diante da disponibilidade de uma nova infraestrutura facilitadora da ação coletiva - as redes sociais digitais -, apareceram como protagonistas (Sorj, 2016; Branco, 2015).

Pesquisas qualitativas junto a coletivos e grupos feministas registram a marcação de diferenças geracionais no interior das variadas formas de ação coletiva da atualidade. Em sua pesquisa sobre a Marcha das Vadias, por exemplo, Gomes e Sorj (2014) registraram disputas internas entre mulheres que se demarcam como "jovens feministas" e as lideranças mais velhas. Essas divergências geracionais costumam se expressar não apenas no quesito ideológico, mas também quanto às estratégias dos movimentos: discutem-se frequentemente as formas de distribuição do poder ("horizontalidade" vs. "verticalidade") e a manutenção da autonomia do grupo face aos outros movimentos e organizações ("autonomia" vs. "institucionalização") (Gomes e Sorj, 2014). Tais discordâncias dão exemplo de como fronteiras e classificações "geracionais" se relacionam com disputas pela repartição do poder e conflitos entre sistemas de aspirações constituídos a partir de diferentes épocas e experiências (Bourdieu, 1983).

Em alguns casos, a marcação da diferença por "jovens" alude também a um uso específico das novas tecnologias: a internet tanto auxiliou no adensamento de redes entre organizações políticas e grupos feministas já existentes, como facilitou a criação de novas redes de comunicação, ação e reflexão desses grupos (Branco, 2015). Algumas das jovens ativistas da Marcha das Vadias, por exemplo, produzem um discurso de diferenciação radical com relação à "geração 80", expresso em falas como esta: "Não formamos quadros ao longo dos últimos trinta anos. Eles estão sendo formados agora, com a internet, mas eu acho que a galera 'das antigas' está meio perdida" (Name e Zanetti, 2013:9).

Ainda que o campo do feminismo não possa ser reduzido a eixos simples, há determinadas características que parecem ser particulares aos "jovens feminismos" online. A "geração 80" se esforçou para demonstrar que aflições que eram então consideradas exclusivamente individuais $e$ da ordem do privado - como a violência doméstica, por exemplo - eram problemas estruturais, de interesse coletivo e pertinentes à esfera pública. A nova geração, por sua vez, tende a adotar teorias 
feministas para ler a si, seu cotidiano, sua subjetividade e relações interpessoais, indo das teorias $e$ generalizações macrossociológicas para o plano micro da vida social.

Isso se expressa em um ativismo que dilui as fronteiras entre o público e o privado, acentua os testemunhos, as emoções, as histórias pessoais e a elaboração de narrativas de si. Como bem resume Bila Sorj, "se o lema 'o pessoal é político' marcou uma geração de feministas, agora ele aparece invertido, [e] 'o político é pessoal'" (Sorj, 2016:5). De fundamental importância é também o lugar conferido às múltiplas posições identitárias das ativistas - ou "interseccionalidades" -, que evidenciam o reconhecimento de que o campo social é atravessado por outros eixos além do gênero, tais como classe, raça, etnia, orientação sexual, deficiência, religião, entre outros (Buarque de Hollanda, 2018).

Apesar das diferenças, pesquisas qualitativas mostram que os coletivos, organizações $e$ mobilizações feministas possuem uma relação muito mais porosa entre o virtual e não-virtual, o institucional $e$ o não institucional, $e$, sobretudo, muito mais fluidez $e$ colaboração entre as "gerações" do que se costuma admitir (Sorj, 2016). Muitas feministas da "nova geração" tampouco se demarcam enquanto "jovens", expressando preferência por outras designações (Alvarez, 2014). Diversos elos e vínculos conectam as várias formas de ativismo através do tempo: não só as ONGs realizaram um trabalho de décadas de formação de públicos, como as universidades, com sua estrutura estável, proporcionaram canais de circulação de saberes e espaços para encontros físicos ao longo desse tempo (Gonçalves, 2016).

Os próprios blogs e sites que ajudaram a impulsionar os "ativismos em rede" tiveram, frequentemente, relação com as ONGs, universidades ou outras organizações feministas mais antigas. Pode-se ainda mencionar as intrincadas conexões que se fazem presentes nas manifestações de rua: seu aparente caráter espontâneo e convocação por iniciativa de coletivos virtuais informais está profundamente articulado a instituições off-line, como ONGs ou departamentos femininos de sindicatos e de partidos, que fornecem recursos materiais, equipamentos e contatos para os atos públicos (Sorj, 2016).

A despeito de tais complexidades, as "gerações" feministas importam porque expressam significados, sentimentos culturais, identidades coletivas, crenças e concepções morais que produzem impactos significativos no campo político do feminismo. Além disso, estão relacionadas a diferenças nas influências culturais e políticas, nas conexões, redes e experiências, nas formas de processar e significar acontecimentos entre as pessoas (Gonçalves, 2016) e, não menos importante, estão associadas a conflitos entre diferentes aspirações e formas de repartição do poder (Bourdieu, 1983). Voltamo-nos agora para a pesquisa de opinião conduzida no 8 de Março, que permite mapear e comparar algumas dessas autorrepresentações.

\section{O campo da pesquisa: o 8 de Março no Rio de Janeiro}

Gestado no interior do movimento socialista europeu, o 8 de Março, ou Dia Internacional da Mulher, faz alusão à greve das trabalhadoras que precipitou processos revolucionários na Rússia em 1917 (González, 2010). No Brasil, a data ganhou impulso a partir do ano de 1975, escolhido pela Organização das Nações Unidas como o Ano Internacional da Mulher (Blay, 2001). Após a efervescência dos anos 1970 e 1980, quando milhares de mulheres foram atraídas às ruas na Europa e nos Estados Unidos, ocorreu o esvaziamento dos anos 1990, marcado por discursos de "pós-feminismo", que apregoavam que a igualdade de gênero já havia sido atingida (Budgeon, 2011). Recentemente, o feminismo voltou a atrair números crescentes às ruas não só da Europa $e$ dos Estados Unidos, mas também do Sul Global. Em meio às reviravoltas, o 8 de Março permaneceu como um "repertório" de ação coletiva: uma prática já experimentada, conhecida e legitimada de contestação consolidada pela sua reiteração no tempo (Della Porta, 2013).

A organização do 8 de Março do ano de 2017 no Rio de Janeiro em forma de ato unificado resultou da coalizão de diversos movimentos populares e feministas, coletivos, ONGs, setoriais de partidos, sindicatos etc. Para esse evento, além do usual ato de rua, convocou-se uma Greve Internacional de Mulheres. A ideia ganhou força graças a ações anteriores como a grande marcha Ni Una a Menos, na Argentina, e a Women's March, nos Estados Unidos. No plano internacional, as pautas divulgadas foram o repúdio à violência contra a mulher e à desvalorização do trabalho 
feminino. No Brasil, o protesto voltou-se também contra as reformas trabalhista e da previdência, que então tramitavam no Congresso Nacional. As organizadoras argumentaram que tais medidas aprofundavam ainda mais as desigualdades de gênero já existentes no país.

Em plenária da organização do 8 de Março no Rio de Janeiro (8MRJ) para um balanço geral do protesto de 2017, as ativistas envolvidas se confessaram surpresas e satisfeitas com o grande número de pessoas que compareceram ao ato ${ }^{1}$. Para elas, o êxito se deveu à grande coalizão entre diversos movimentos, à construção de pautas comuns, ao chamado internacional e à divulgação massiva nas redes sociais digitais. As organizadoras surpreenderam-se também com uma grande presença de mulheres jovens autônomas, isto é, sem filiação a movimentos ou partidos. Quanto à ideia de paralisação, bem-sucedida na Argentina, as ativistas apontaram dificuldades, particularmente pela não adesão das centrais sindicais e por consequência da dificuldade de realizar greves em uma economia tão informal como a brasileira.

\section{Metodologia}

Nas pesquisas de opinião feitas em passeatas um dos maiores desafios está em selecionar os manifestantes que serão entrevistados de modo a garantir uma amostra representativa. Não se conhece previamente as características da população manifestante para que se possa estabelecer, por exemplo, "cotas" de representação do perfil da população em estudo (Johnson, Reynold e Mycoff, 2015). Para contornar esse problema, seguimos metodologia desenvolvida e testada em outras oportunidades por Borba (2017), que busca dar a todos os participantes de uma manifestação a chance de serem incluídos na amostra $e$, portanto, evitar que haja um viés de seleção.

O procedimento consiste em distribuir a equipe de pesquisadores por toda a extensão da passeata, iniciando a distribuição de questionários desde o horário de início até mais próximo ao de encerramento. Na nossa pesquisa, a primeira equipe chegou ao local às $16 \mathrm{~h}$ e as demais, sucessivamente, às $17 \mathrm{~h}, 18 \mathrm{~h}$ e $19 \mathrm{~h}$, acompanhando o trajeto da Candelária até a Praça XV, no Centro do Rio de Janeiro. Em todos os horários, as entrevistadoras dividiram-se ao longo da marcha: uma equipe cobriu a parte da frente; outra, a parte intermediária e a última, a parte de trás. Esse procedimento evita que a decisão de escolher o entrevistado/a caiba inteiramente a/o entrevistador/a.

Há diferenças significativas no perfil dos ativistas entrevistados em manifestações quando o método escolhido não é randômico (Walgrave e Verhulst, 2011). Quando a decisão é exclusivamente do entrevistador, a amostra tende a sobrerrepresentar pessoas com mais escolaridade e interesse por política. Por esse motivo, as nossas entrevistadoras, todas mulheres, foram orientadas a não buscar ativamente entrevistadas na multidão. Após o fim de uma entrevista ou recusa de uma manifestante, a entrevistadora deveria abordar a primeira pessoa que passasse na sua frente no intervalo de um a dois minutos. Como as passeatas caminham homogeneamente na mesma direção, o intervalo de tempo é adequado, pois altera a composição das pessoas próximas da entrevistadora, aproximando o processo de uma escolha aleatória. Na passeata, foram coletadas 152 entrevistas.

\section{Operacionalização de variáveis}

"Operacionalização" é um termo que designa as decisões teóricas que tomamos em uma pesquisa quantitativa para a construção de variáveis. Como a pesquisa quantitativa trabalha com a transformação de perguntas de pesquisa complexas em variáveis simples, o processo implica inevitavelmente em perdas e escolhas (Lima, 2016). No nosso caso, as principais categorias empregadas na análise dos dados foram construídas a partir das respostas espontâneas das

\footnotetext{
1 A fim de entender as diferentes expressões do feminismo atual, o survey foi complementado com pesquisas in loco junto aos grupos Marcha Mundial das Mulheres, partidA, $8 \mathrm{MRJ}$ e nas plenárias de organização das manifestações. Isso permitiu criar um repertório das formas de mobilização, as redes, a construção das pautas, as estratégias de protesto e as formas de comunicação das organizadoras, ajudando a compreender melhor a formação do espaço público do feminismo na atualidade.
} 
entrevistadas: primeiro fizemos perguntas abertas sobre gênero e idade para só depois agrupar as respostas em torno das categorias mais incidentes. Por exemplo, ao perguntarmos a elas "Qual é o seu gênero?", permitimos que respondessem com suas próprias palavras. Como resultado, obtivemos como respostas mais frequentes "mulher cisgênero", "mulher cis", "cis", "feminino", "mulher", "heterossexual", "bissexual", "mulher transgênero" e "não sei". Esse procedimento nos permitiu utilizar categorias mais próximas das visões reais das entrevistadas em vez de impor termos pré-estabelecidos (Fowler Jr., 2011) ${ }^{2}$. Isso é importante quando se deseja trabalhar com gênero como categoria analítica e não descritiva (Scott, 1995). Pessoas que se classificaram como "homens" foram excluídas da amostra.

A variável "idade" ou "geração" tem uma operacionalização mais difícil. Tem-se criticado as pesquisas sobre "juventude" que trabalham essa categoria sem um referencial teórico claro, $e$ particularmente aquelas que naturalizam a idade cronológica como um dado biológico, pré-social e pré-linguístico. Ao tratar idade e geração como sinônimos, deixa-se de investigar os próprios fenômenos sociais e culturais que produzem esse marcador social, bem como a sua interação com eixos como classe, raça e gênero. Para lidar com esse problema, sugere-se que a própria dificuldade de definição conceitual de juventude seja problematizada na análise (Zanella et al., 2013).

Tendo isso em vista, com relação à "geração", o nosso procedimento seguiu duas etapas. Primeiro, cruzamos as respostas relativas a pautas feministas com diferentes características sociais das entrevistadas. A partir desses cruzamentos, foi possivel observar que as variações mais significativas de opinião entre as entrevistadas davam-se por idade - e não por outras características como cor, renda, escolaridade, orientação sexual. Nossa estratégia analítica consistiu em agrupar as idades por quartis, isto é, em separar a amostra em quatro grupos de idade que concentram $25 \%$ dos casos em cada um. Essa distribuição permite análises comparativas equilibradas, sem distorções dos resultados pela distribuição desigual de números de casos. Como resultado, trabalhamos com as faixas de "15 a 25 anos", "26 a 30 anos", "31 a 43 anos" e "Acima de 44 anos". Assim, admitimos como válida a hipótese de que haja uma relação a ser testada entre identidade, opinião e geração. Apesar de reconhecermos como problemática a utilização da idade como proxy de "geração" (Gonçalves e Pinto, 2011), com essa estratégia, conseguimos uma operacionalização estatística dos dados.

\section{Resultados}

\section{Perfis Sociodemográficos}

Os resultados do survey apontam que o público presente na manifestação feminista do 8 de Março no Rio de Janeiro possuía um perfil sociodemográfico facilmente identificável: as mulheres presentes eram majoritariamente jovens, solteiras, sem filhos, heterossexuais, com proporções equilibradas entre brancas e pretas ou pardas, de escolaridade muito alta e com renda média ou baixa ${ }^{3}$. Visto que as pesquisas qualitativas indicam que as feministas da geração passada eram majoritariamente brancas, de classe média e alta, mais velhas e portadoras de diploma superior (Gonçalves, 2016), os dados do 8 de Março expressam mudanças e reconfigurações no campo do feminismo, sobretudo na sua composição social, racial, etária e de classe.

\footnotetext{
2 Ainda assim, por se tratar de uma pesquisa quantitativa, as respostas anotadas são sucintas e não é possível ter acesso à visão de mundo detalhada das respondentes.

3 Ainda assim, identificou-se bastante heterogeneidade. A média aritmética de idade, por exemplo, foi de 35 anos e a mediana de 30 anos, mas houve também uma participação relevante de mulheres com mais de 40 anos. A entrevistada mais nova tinha 15 anos e a mais velha, 77. O perfil sociodemográfico identificado se assemelha àquele delineado por outro estudo quantitativo, realizado na Marcha das Vadias em 2012 (Name e Zanetti, 2013).
} 
Tabela 1: Perfil sociodemográfico

\begin{tabular}{|l|c|l|c|}
\hline Escolaridade & $\mathbf{\%}$ & Renda** & $\mathbf{\%}$ \\
\hline Pós-Graduação & 34,2 & Acima de 10 SM & 11,8 \\
\hline Superior & 50,0 & Entre 5 e 10 SM & 19,7 \\
\hline Médio & 14,5 & Entre 2 e 5 SM & 25,7 \\
\hline Fundamental & 1,3 & Até 2 SM & 25,0 \\
\hline Cor & $\mathbf{\%}$ & Filhos & \% \\
\hline Branca & 44,1 & Sem filhos & 69,7 \\
\hline Parda & 18,4 & 1 filho & 17,1 \\
\hline Preta & 25,0 & 2 filhos & 7,2 \\
\hline Outras* & 12,5 & 3 ou + filhos & 5,9 \\
\hline Estado Civil & $\%$ & Faixas de idade & $\%$ \\
\hline Solteira & 67,8 & 15 a 24 anos & 20,3 \\
\hline $\begin{array}{l}\text { Casada / União } \\
\text { estável }\end{array}$ & 16,4 & 25 a 34 anos & 41,2 \\
\hline Divorciada & 7,9 & 35 a 44 anos & 15,0 \\
\hline Viúva & 5,9 & 45 a 60 anos & 15,7 \\
\hline Outros & 2,0 & Acima de 60 anos & 7,8 \\
\hline
\end{tabular}

* Outras: indígenas $(2,6 \%)$, amarelas $(2 \%)$ e outras $(7,9 \%)$.

** 17,8\% afirmaram não ter renda própria.

Fonte: Elaboração própria. $\mathrm{N}=152$.

Até recentemente, supunha-se que as experiências catalisadoras da consciência feminista eram o casamento, a maternidade, a sexualidade e o trabalho formal (Gonçalves e Pinto, 2011). Nossos dados sugerem que isso mudou: a maioria das feministas que ocuparam as ruas no 8 de Março não experimentaram a maternidade e o casamento. Uma grande parte não viveu a experiência no mercado de trabalho. Além disso, como veremos mais adiante, a sexualidade permanece como experiência importante, mas assume novos significados.

Pesquisas qualitativas podem contribuir para elucidar que outras socializações e experiências do curso da vida estão contribuindo para a formação de uma nova geração de feministas, mas é provável que a escolaridade das entrevistadas forneça uma pista para compreender ao menos em qual espaço essa formação está ocorrendo: independentemente da sua renda ou cor, a maioria delas $(84,2 \%)$ fez ou está fazendo um curso universitário.

Com efeito, há muitas décadas, as universidades têm fornecido um espaço e uma estrutura fundamental para o feminismo brasileiro: nos anos 1970, formaram-se nas universidades os primeiros coletivos informais e, nas décadas seguintes, floresceram os núcleos de estudos e pesquisa liderados por docentes identificadas com o campo de estudos feministas e de gênero (Corrêa, 2001).

Hoje, atendendo a um público ampliado e muito mais diverso, as universidades continuam a favorecer encontros físicos e formação de redes. Sabe-se que a formação de uma "geração" exige uma determinada socialização comum (Gonçalves e Pinto, 2011) e que a própria categoria "juventude" tem um vínculo histórico com o prolongamento do estudo e postergação do ingresso no mercado de trabalho: a vida de secundarista ou de universitário produz a possibilidade de vivenciar posições exteriores ao universo "adulto" e experimentar a condição de "jovem" (Bourdieu, 1983).

Por todos esses motivos, sugerimos que a expansão e a democratização do Ensino Superior ocorridas nos anos 2000 tiveram um papel de impulsionar o feminismo. A socialização que está em curso passa pela circulação de saberes sobre gênero e feminismo nos núcleos, institutos e programas universitários, mas também ocorre em espaços constituídos e mantidos pelas próprias estudantes, como coletivos e atividades políticas, artísticas e culturais. 
Gênero, orientação sexual e geração

Dando sequência à caracterização sociodemográfica das manifestantes, perguntamos a elas "Qual é a sua identidade de gênero?" e registramos suas respostas espontâneas. O resultado foram mais de 15 respostas diferentes: uma parte bastante expressiva $(36,2 \%)$ recorreu ao prefixo "cis" ("mulher cis", "cisgênero", "cis feminino", "cis", "cis mulher") para qualificar sua identidade e 4,6\% delas aludiram à sua orientação sexual ("bi", "hetero" ou "heterossexual") como sua "identidade de gênero". Finalmente, outra fração muito significativa $(57,2 \%)$ respondeu simplesmente "mulher" ou "gênero feminino". Apenas uma pessoa se declarou "mulher trans" $(0,7 \%)$.

As respostas variaram significativamente com a faixa de idade. Como é possível perceber na tabela abaixo, as mais jovens empregaram os termos "cis" e "cisgênero" mais frequentemente que as mais velhas. Tendo em vista que as identidades são relacionais, o uso do termo "cisgênero" pelas mais jovens demonstra atenção às identidades "transgênero" e também expressa familiaridade com o léxico acadêmico e ativista contemporâneo sobre gênero - associado à leitura pós-estruturalista $e$ construtivista das identidades.

Tabela 2: Identidade de gênero e idade

\begin{tabular}{|l|c|c|c|c|c|c|}
\hline & $\begin{array}{c}\text { Mulher } \\
\text { cisgênero,mul } \\
\text { her cis, cis }\end{array}$ & $\begin{array}{c}\text { Feminino, } \\
\text { mulher }\end{array}$ & $\begin{array}{c}\text { Heterossexual, } \\
\text { bissexual }\end{array}$ & $\begin{array}{c}\text { Mulher } \\
\text { transgênero }\end{array}$ & Não sei & Total \\
\hline $\begin{array}{l}15 \text { a } 25 \\
\text { anos }\end{array}$ & $42,1 \%$ & $47,4 \%$ & $7,9 \%$ & $0,0 \%$ & $2,6 \%$ & $100,0 \%$ \\
\hline $\begin{array}{l}26 \text { a } 30 \\
\text { anos }\end{array}$ & $41,0 \%$ & $51,3 \%$ & $5,1 \%$ & $2,6 \%$ & $0,0 \%$ & $100,0 \%$ \\
\hline $\begin{array}{l}31 \text { a } 43 \\
\text { anos }\end{array}$ & $35,1 \%$ & $59,5 \%$ & $2,7 \%$ & $0,0 \%$ & $2,7 \%$ & $100,0 \%$ \\
\hline $\begin{array}{l}\text { Acima } \\
\text { de 44 } \\
\text { anos }\end{array}$ & $26,3 \%$ & $71,1 \%$ & $2,6 \%$ & $0,0 \%$ & $0,0 \%$ & $100,0 \%$ \\
\hline Total & $36,2 \%$ & $57,2 \%$ & $4,6 \%$ & $0,7 \%$ & $1,3 \%$ & $100,0 \%$ \\
\hline
\end{tabular}

Fonte: Elaboração própria. N = 152.

Outro dado que assumiu matizes geracionais foi a questão da orientação sexual. A maioria das entrevistadas $(65,8 \%)$ se declarou heterossexual, mas, quando correlacionamos com idade, notamos um padrão de associação nítido entre ser mais jovem e declarar outras orientações sexuais, como homossexual e bissexual. No caso das mulheres acima de 44 anos, por exemplo, $94,7 \%$ declararam ser heterossexuais, enquanto esse percentual caiu para $42 \%$ entre aquelas de 15 a 25 anos.

Tabela 3: Orientação sexual e idade

\begin{tabular}{|c|c|c|c|c|c|c|}
\hline & Homossexual & Heterossexual & Bissexual & Pansexual & Outros & Total \\
\hline $\begin{array}{c}15 \text { a } 25 \\
\text { anos }\end{array}$ & $18,4 \%$ & $42,1 \%$ & $31,6 \%$ & $2,6 \%$ & $5,3 \%$ & $100,0 \%$ \\
\hline $\begin{array}{c}26 \text { a } 30 \\
\text { anos }\end{array}$ & $7,7 \%$ & $51,3 \%$ & $30,8 \%$ & $7,7 \%$ & $2,6 \%$ & $100,0 \%$ \\
\hline $\begin{array}{c}31 \text { a } 43 \\
\text { anos }\end{array}$ & $8,1 \%$ & $75,7 \%$ & $13,5 \%$ & $0,0 \%$ & $2,7 \%$ & $100,0 \%$ \\
\hline $\begin{array}{c}\text { Acima de } \\
44 \text { anos }\end{array}$ & $0,0 \%$ & $94,7 \%$ & $2,6 \%$ & $0,0 \%$ & $2,6 \%$ & $100,0 \%$ \\
\hline Total & $8,6 \%$ & $65,8 \%$ & $19,7 \%$ & $2,6 \%$ & $3,3 \%$ & $100,0 \%$ \\
\hline
\end{tabular}

Fonte: Elaboração própria. N = 152. 
Partido e perfil político

O perfil político das participantes foi bastante homogêneo ${ }^{4}$ : a ampla maioria se posicionou na esquerda $(85,5 \%)$ ou centro-esquerda $(4,6 \%)$ e 9,1\% disseram não ter preferência ideológica ou não sabiam opinar. Apenas uma respondente $(0,7 \%)$ se disse de direita. Comparado ao perfil observado entre militantes na passeata LGBT ocorrida em Copacabana em dezembro de 2016, por exemplo, as militantes feministas do 8 de Março pendem significativamente mais à esquerda do que participantes de outras manifestações: na Parada LGBT, 52\% dos participantes se disseram de esquerda (Borba, 2017), enquanto, no 8 de Março, esse percentual foi de 90,1\%.

Se não houve diferenças geracionais expressivas quanto à orientação política, a variação mais notável aconteceu na identificação partidária. Nos dados globais, a identificação com um partido específico apresentou números elevados em comparação com a população geral: cerca de $63 \%$ das manifestantes tinham preferência por algum partido político ${ }^{5}$. Nota-se, claramente, que as manifestantes entrevistadas compunham uma faixa do eleitorado com forte predisposição política $e$ com vínculos ativos com os partidos. Quando olhamos a distribuição de preferência partidária por idade, constatamos uma clara preferência das mais jovens pelo PSOL. Essa preferência já foi registrada em outras pesquisas conduzidas no Rio de Janeiro (Datafolha, 2016), não sendo característica exclusiva dessa manifestação específica.

Tabela 4: Identificação partidária e idade (estimulada e única)

\begin{tabular}{|l|l|l|l|l|l|l|l|l|}
\hline & PSOL & PT & PCB & $\begin{array}{c}\text { PSOL/P } \\
\mathrm{T}\end{array}$ & $\begin{array}{c}\text { PSOL/P } \\
\text { CB }\end{array}$ & Outros & $\begin{array}{c}\text { Nenhum } \\
\text { partido }\end{array}$ & Total \\
\hline $\begin{array}{l}15 \text { a } 25 \\
\text { anos }\end{array}$ & $34,2 \%$ & $2,6 \%$ & $0,0 \%$ & $7,9 \%$ & $5,3 \%$ & $0,0 \%$ & $50,0 \%$ & $100,0 \%$ \\
\hline $\begin{array}{l}26 \text { a } 30 \\
\text { anos }\end{array}$ & $38,5 \%$ & $12,8 \%$ & $2,6 \%$ & $0,0 \%$ & $0,0 \%$ & $5,1 \%$ & $41,0 \%$ & $100,0 \%$ \\
\hline $\begin{array}{l}31 \text { a } 43 \\
\text { anos }\end{array}$ & $51,4 \%$ & $13,5 \%$ & $2,7 \%$ & $0,0 \%$ & $2,7 \%$ & $0,0 \%$ & $29,7 \%$ & $100,0 \%$ \\
\hline $\begin{array}{l}\text { Acima de } \\
44 \text { anos }\end{array}$ & $31,6 \%$ & $21,1 \%$ & $0,0 \%$ & $5,3 \%$ & $0,0 \%$ & $13,2 \%$ & $28,9 \%$ & $100,0 \%$ \\
\hline Total & $38,8 \%$ & $12,5 \%$ & $1,3 \%$ & $3,3 \%$ & $2,0 \%$ & $4,6 \%$ & $37,5 \%$ & $100,0 \%$ \\
\hline
\end{tabular}

Fonte: Elaboração própria. $\mathrm{N}=152$.

\section{Dinâmicas de mobilização}

Em outro módulo de perguntas, inquirimos as respondentes em pergunta de resposta múltipla a respeito de como elas tomaram conhecimento da passeata. No 8 de Março, a maior parte das manifestantes $(53,9 \%)$ afirmou ter sabido do protesto pelas redes sociais. Muitas delas $(18,3 \%)$ mencionaram colegas e amigas, enquanto algumas se referiram a movimentos sociais $(6,8 \%)$, sindical $(4,1 \%)$ e feminista $(5 \%)$. Suportes de comunicação tradicionais como TV, rádio, jornal tiveram pouca expressão $(1,8 \%)$, assim como formas tradicionais de divulgação como panfletos $(0,5 \%)$. Nota-se também a baixa relevância dos partidos como agentes mobilizadores visíveis $(1,4 \%)$.

Esses dados não permitem inferir que os partidos políticos e sindicatos não são ativos na organização do protesto, o que fica claro na pesquisa de campo realizada junto à organização do 8 de Março: ao longo das plenárias de organização, frequentemente a filiação político-partidária das integrantes do 8MRJ ou sua participação em sindicatos e organizações feministas causava desconfiança e provocava recuos na formação de alianças e produção de ações coletivas entre elas,

\footnotetext{
4 As opções apresentadas às entrevistadas foram "esquerda", "centro-esquerda", "centro", "centro-direita" e "direita".

5 Esses números destoam significativamente da realidade cidade do Rio de Janeiro. Em uma pesquisa realizada pelo Datafolha durante o primeiro turno das eleições para prefeito da cidade em 2016 , apenas $26,5 \%$ declararam possuir preferência por algum partido político (Datafolha Instituto de Pesquisas, 2016).
} 
particularmente pelo temor do "aparelhamento" da manifestação por partidos políticos - ao que sempre se contrapunham os discursos da "autonomia" e da "horizontalidade".

Ao mesmo tempo, a estrutura material proporcionada por essas organizações desempenhou papel muito importante na articulação do $8 \mathrm{MRJ}$ e na realização do ato ocorrido no dia 8 de março. A presença dos partidos na organização não implica, contudo, que eles tenham sido decisivos no recrutamento para as ruas. Por fim, quando relacionamos a pergunta à questão geracional, reparamos que, entre as mais velhas, outras formas de mobilização ganham muito mais importância, como os movimentos sociais, o movimento sindical e formas tradicionais de comunicação, como TV, rádio, jornal, ou mesmo a própria referência à data de 8 de março como dia de protesto das mulheres.

Tabela 5: Forma de mobilização e idade (espontânea e múltipla)

\begin{tabular}{|l|c|c|c|c|}
\hline & $\begin{array}{c}15 \text { a } 25 \\
\text { anos }\end{array}$ & $\begin{array}{c}26 \text { a } 30 \\
\text { anos }\end{array}$ & $\begin{array}{c}31 \text { a } 43 \\
\text { anos }\end{array}$ & $\begin{array}{c}\text { Acima de } \\
44 \text { anos }\end{array}$ \\
\hline Colegas, amigas/os & $23,7 \%$ & $31,6 \%$ & $31,4 \%$ & $21,6 \%$ \\
\hline Redes sociais & $92,1 \%$ & $78,9 \%$ & $85,7 \%$ & $62,2 \%$ \\
\hline $\begin{array}{l}\text { Pertence à organização } \\
\text { do ato }\end{array}$ & $0,0 \%$ & $7,9 \%$ & $2,9 \%$ & $2,7 \%$ \\
\hline Escola & $7,9 \%$ & $0,0 \%$ & $0,0 \%$ & $0,0 \%$ \\
\hline Universidade & $5,3 \%$ & $0,0 \%$ & $2,9 \%$ & $2,7 \%$ \\
\hline Movimento social & $0,0 \%$ & $10,5 \%$ & $17,1 \%$ & $13,5 \%$ \\
\hline Movimento feminista & $5,3 \%$ & $5,3 \%$ & $11,4 \%$ & $8,1 \%$ \\
\hline Movimento Sindical & $0,0 \%$ & $0,0 \%$ & $0,0 \%$ & $24,3 \%$ \\
\hline Partido & $2,6 \%$ & $0,0 \%$ & $2,9 \%$ & $2,7 \%$ \\
\hline Panfleto & $0,0 \%$ & $2,6 \%$ & $0,0 \%$ & $0,0 \%$ \\
\hline Mídia (TV, rádio, jornal) & $0,0 \%$ & $0,0 \%$ & $5,7 \%$ & $5,4 \%$ \\
\hline Data 8 de março & $2,6 \%$ & $0,0 \%$ & $2,9 \%$ & $5,4 \%$ \\
\hline Outros & $0,0 \%$ & $0,0 \%$ & $2,9 \%$ & $2,7 \%$ \\
\hline
\end{tabular}

Fonte: Elaboração própria. N = 152.

Quando estimuladas a responder espontaneamente o motivo para a sua participação no protesto, 29,4\% das manifestantes do 8 de Março apontaram, entre outras razões, a necessidade de protestar contra a reforma trabalhista e/ou a reforma da previdência, naquele momento em discussão no Congresso Nacional. Esse número foi puxado pelas mulheres mais velhas: enquanto $25 \%$ das manifestantes de 15 a 25 anos fizeram alusão a essa pauta, entre as mulheres acima de 44 anos, o percentual foi de $51,4 \%$.

Como a pergunta realizada foi aberta, o número total de categorias tabuladas foi muito grande (21), justamente para permitir inferências específicas com relação aos grupos de idade. Mas, de modo geral, é possível perceber algumas tendências quando agrupamos as respostas em conjuntos de temas. As mulheres com mais de 44 anos se destacaram pela adesão mais forte a pautas políticas ligadas à conjuntura, como a oposição às reformas trabalhista $e$ da previdência $e$ contra o governo de Michel Temer.

Como vimos na Tabela 5, é notável, entre essas manifestantes mais velhas, a presença mais significativa dos sindicatos e movimentos sociais como mobilizadores para o protesto, o que pode explicar sua maior adesão a pautas de caráter mais amplo. O tipo e a forma das redes que levam as pessoas às ruas - ou seja, as conexões físicas ou virtuais entre as pessoas - frequentemente têm relação com os enquadramentos e pautas que as mobilizam (Jasper, 2014).

Em outros casos, é interessante notar a influência do ciclo de vida das mulheres na menção espontânea a determinadas pautas feministas: as mulheres na faixa entre 26 e 30, assim como aquelas entre 31 e 43 anos, salientaram agendas ligadas à igualdade no mercado de trabalho $e$ divisão sexual do trabalho com mais frequência, tanto quando comparadas com as mais jovens, 
quanto com às mais velhas. As mais jovens de todas, isto é, aquelas entre 15 e 25 anos, foram praticamente as únicas a apontar temas como liberdade sexual e combate à homofobia $e$ lesbofobia, o que demonstra a importância da sexualidade como experiência catalisadora da sua militância.

Tabela 6: Motivos da Participação na Manifestação por idade (espontânea e múltipla)

\begin{tabular}{|c|c|c|c|c|c|}
\hline & $\begin{array}{c}15 \text { a } 25 \\
\text { anos }\end{array}$ & $\begin{array}{c}26 \text { a } 30 \\
\text { anos }\end{array}$ & $\begin{array}{c}31 \text { a } 43 \\
\text { anos }\end{array}$ & $\begin{array}{l}\text { Acima de } \\
44 \text { anos }\end{array}$ & Total \\
\hline $\begin{array}{l}\text { Reforma trabalhista, da previdência, } \\
\text { medidas neoliberais e retrocessos } \\
\text { sociais; Contra o golpe; Levada por } \\
\text { partido, sindicato, movimento social; } \\
\text { Luta anticapitalista }\end{array}$ & $28,9 \%$ & $30,8 \%$ & $29,7 \%$ & $68,4 \%$ & $39,5 \%$ \\
\hline $\begin{array}{l}\text { Internacionalismo feminista; } \\
\text { Fortalecimento do movimento de } \\
\text { mulheres, solidariedade entre mulheres; } \\
\text { Visibilidade pública da luta de } \\
\text { mulheres; Conhecendo o } 8 \text { de Março }\end{array}$ & $50,0 \%$ & $56,4 \%$ & $64,9 \%$ & $42,1 \%$ & $53,3 \%$ \\
\hline $\begin{array}{l}\text { Equiparação salarial, de oportunidades } \\
\text { e igualdade de gênero no trabalho; } \\
\text { Maternidade, direitos das mães, divisão } \\
\text { sexual do trabalho, tripla jornada, } \\
\text { creche; Representação política e em } \\
\text { espaços de poder }\end{array}$ & $10,5 \%$ & $15,4 \%$ & $21,6 \%$ & $2,6 \%$ & $12,5 \%$ \\
\hline $\begin{array}{llll}\begin{array}{l}\text { Liberdade sexual; } \\
\text { lesbofobia }\end{array} & \text { Homofobia } & e \\
\end{array}$ & $18,4 \%$ & $0,0 \%$ & $0,0 \%$ & $2,6 \%$ & $5,3 \%$ \\
\hline $\begin{array}{l}\text { Assédio e estupro; Feminicídio, } \\
\text { violência contra a mulher e/ou } \\
\text { violência doméstica; Segurança da } \\
\text { mulher nos espaços públicos da cidade }\end{array}$ & $5,3 \%$ & $41,0 \%$ & $40,5 \%$ & $15,8 \%$ & $25,7 \%$ \\
\hline $\begin{array}{l}\text { Descriminalização do aborto e direitos } \\
\text { reprodutivos; Violência obstétrica }\end{array}$ & $2,6 \%$ & $5,1 \%$ & $13,5 \%$ & $0,0 \%$ & $8,6 \%$ \\
\hline $\begin{array}{l}\text { Igualdade de direitos; Machismo e } \\
\text { Patriarcado; Racismo }\end{array}$ & $42,1 \%$ & $35,9 \%$ & $27,0 \%$ & $34,2 \%$ & $34,9 \%$ \\
\hline
\end{tabular}

Fonte: Elaboração própria. $\mathrm{N}=152$.

Nosso questionário contemplava duas perguntas semelhantes: os motivos para a participação naquela manifestação específica e quais eram as principais pautas feministas na opinião da entrevistada (cujas respostas aparecem na tabela 7). No primeiro caso, a questão do combate às reformas da previdência e trabalhista foi a mais mencionada, seguida por visibilidade pública da luta das mulheres, igualdade de direitos $e$ fortalecimento interno do movimento de mulheres/solidariedade.

$\mathrm{Na}$ outra questão, perguntamos às mulheres quais são as suas principais reivindicações no movimento feminista. Os motivos mais citados foram aqueles que se atribuem tipicamente à dita "segunda onda" feminista (Budgeon, 2011): protestar contra o feminicídio e a violência contra a mulher, exigir a igualdade de direitos, dar visibilidade pública e fortalecer o feminismo, protestar contra as reformas trabalhista e da previdência, demandar a equiparação salarial, de oportunidades $e$ igualdade de gênero no trabalho e pleitear a descriminalização do aborto e direitos reprodutivos.

Com respostas muito pulverizadas entre muitas categorias, não identificamos diferenças significativas entre as prioridades das faixas de idade. No entanto, a própria ausência dessas diferenças é um dado significativo em si, que já foi notado por outras pesquisadoras. Eliane Gonçalves e Joana Pinto (2011), por exemplo, apontaram que as principais divergências observadas entre gerações não se dão com relação às pautas: essas permaneceram estáveis nos últimos 20 ou 30 anos, organizadas em torno da igualdade salarial, maternidade voluntária, saúde sexual e reprodutiva, autonomia e combate à violência. Segundo elas, as tensões estariam ligadas sobretudo ao reconhecimento da multiplicidade de formas de experimentar gênero - abarcada pelo 
conceito de "interseccionalidade" - e à problemática da divisão do poder no interior dos movimentos feministas (Gonçalves e Pinto, 2011).

Tabela 7:Reivindicações dentro do movimento feminista (espontânea e múltipla)

\begin{tabular}{|c|c|c|c|c|}
\hline & $\begin{array}{c}15 \text { a } 25 \\
\text { anos }\end{array}$ & $\begin{array}{c}26 \text { a } 30 \\
\text { anos }\end{array}$ & $\begin{array}{l}31 \text { a } 43 \\
\text { anos }\end{array}$ & $\begin{array}{l}\text { Acima de } \\
44 \text { anos }\end{array}$ \\
\hline Representação política e em espaços de poder & $10,8 \%$ & $5,3 \%$ & $5,9 \%$ & $2,7 \%$ \\
\hline Igualdade de direitos & $16,2 \%$ & $23,7 \%$ & $14,7 \%$ & $32,4 \%$ \\
\hline $\begin{array}{l}\text { Equiparação salarial, de oportunidades e } \\
\text { igualdade de gênero no trabalho }\end{array}$ & $29,7 \%$ & $21,1 \%$ & $32,4 \%$ & $35,1 \%$ \\
\hline $\begin{array}{l}\text { Maternidade, direitos das mães, divisão sexual } \\
\text { do trabalho, tripla jornada, creche }\end{array}$ & $2,7 \%$ & $5,3 \%$ & $17,6 \%$ & $10,8 \%$ \\
\hline $\begin{array}{l}\text { Reforma trabalhista, da previdência, medidas } \\
\text { neoliberais e retrocessos sociais }\end{array}$ & $2,7 \%$ & $13,2 \%$ & $14,7 \%$ & $21,6 \%$ \\
\hline Igualdade de gênero na escola & $0,0 \%$ & $2,6 \%$ & $0,0 \%$ & $2,7 \%$ \\
\hline Representatividade na mídia & $0,0 \%$ & $2,6 \%$ & $0,0 \%$ & $2,7 \%$ \\
\hline Autoaceitação do corpo & $0,0 \%$ & $2,6 \%$ & $0,0 \%$ & $0,0 \%$ \\
\hline Machismo e patriarcado & $16,2 \%$ & $5,3 \%$ & $2,9 \%$ & $8,1 \%$ \\
\hline Racismo & $2,7 \%$ & $5,3 \%$ & $14,7 \%$ & $8,1 \%$ \\
\hline Assédio e estupro & $10,8 \%$ & $10,5 \%$ & $5,9 \%$ & $2,7 \%$ \\
\hline $\begin{array}{l}\text { Feminicídio, violência contra a mulher e/ou } \\
\text { violência doméstica }\end{array}$ & $32,4 \%$ & $34,2 \%$ & $47,1 \%$ & $29,7 \%$ \\
\hline $\begin{array}{l}\text { Segurança da mulher nos espaços públicos da } \\
\text { cidade }\end{array}$ & $8,1 \%$ & $7,9 \%$ & $20,6 \%$ & $8,1 \%$ \\
\hline $\begin{array}{l}\text { Descriminalização do aborto e direitos } \\
\text { reprodutivos }\end{array}$ & $37,8 \%$ & $26,3 \%$ & $32,4 \%$ & $16,2 \%$ \\
\hline Violência obstétrica & $0,0 \%$ & $2,6 \%$ & $2,9 \%$ & $0,0 \%$ \\
\hline Liberdade sexual & $8,1 \%$ & $7,9 \%$ & $5,9 \%$ & $8,1 \%$ \\
\hline Transfobia e/ou lgbtfobia & $8,1 \%$ & $2,6 \%$ & $2,9 \%$ & $2,7 \%$ \\
\hline Homofobia e lesbofobia & $2,7 \%$ & $0,0 \%$ & $0,0 \%$ & $0,0 \%$ \\
\hline $\begin{array}{l}\text { Fortalecimento do movimento de mulheres, } \\
\text { solidariedade entre mulheres }\end{array}$ & $5,4 \%$ & $5,3 \%$ & $0,0 \%$ & $0,0 \%$ \\
\hline Visibilidade pública da luta de mulheres & $5,4 \%$ & $0,0 \%$ & $0,0 \%$ & $0,0 \%$ \\
\hline Abolição da prostituição & $2,7 \%$ & $0,0 \%$ & $0,0 \%$ & $0,0 \%$ \\
\hline Luta anticapitalista & $2,7 \%$ & $2,6 \%$ & $0,0 \%$ & $5,4 \%$ \\
\hline Moradia & $0,0 \%$ & $0,0 \%$ & $0,0 \%$ & $2,7 \%$ \\
\hline Encarceramento de mulheres & $2,7 \%$ & $0,0 \%$ & $0,0 \%$ & $0,0 \%$ \\
\hline
\end{tabular}

Fonte: Elaboração própria. N = 152.

Atividades de militância

A pesquisa também buscou saber quais são as atividades relacionadas ao feminismo mais praticadas pelas manifestantes. As manifestações de rua destacam-se entre todos os grupos de idade, assim como palestras e rodas de conversa e atividades artístico-culturais. A maior diferença geracional se deu quanto ao ativismo online, menos reportado pelas mulheres mais velhas, $e$ atividades político-partidárias: enquanto poucas das feministas muito jovens afirmaram participar de atividades de partidos políticos, esse índice aumentou significativamente com a idade das mulheres. 
Tabela 8: De quais atividades ligadas ao feminismo você costuma participar? (estimulada e múltipla)

\begin{tabular}{|l|c|c|c|c|}
\hline & $\begin{array}{c}15 \text { a } 25 \\
\text { anos }\end{array}$ & $\begin{array}{c}26 \text { a } 30 \\
\text { anos }\end{array}$ & $\begin{array}{c}31 \text { a } 43 \\
\text { anos }\end{array}$ & $\begin{array}{c}\text { Acima de } \\
44 \text { anos }\end{array}$ \\
\hline Manifestações e ações de rua & $73,7 \%$ & $87,2 \%$ & $78,4 \%$ & $81,6 \%$ \\
\hline Ativismo on-line & $71,1 \%$ & $51,3 \%$ & $54,1 \%$ & $50,0 \%$ \\
\hline Palestras e rodas de conversa & $63,2 \%$ & $71,8 \%$ & $59,5 \%$ & $63,2 \%$ \\
\hline Atividades artístico-culturais & $44,7 \%$ & $48,7 \%$ & $37,8 \%$ & $34,2 \%$ \\
\hline Voluntariado e ações sociais & $18,4 \%$ & $33,3 \%$ & $10,8 \%$ & $28,9 \%$ \\
\hline Político-partidária & $2,6 \%$ & $17,9 \%$ & $18,9 \%$ & $26,3 \%$ \\
\hline Outras & $2,6 \%$ & $7,7 \%$ & $2,7 \%$ & $7,9 \%$ \\
\hline
\end{tabular}

Fonte: Elaboração própria. $\mathrm{N}=152$

As fontes de informações também são diversas, mas há forte influência das tecnologias digitais - seja por meio das redes sociais ou por blogs especializados e canais do YouTube. Palestras, coletivos, movimentos sociais e livros também aparecem como fontes de informação relevantes. Há certo descrédito com relação à mídia tradicional. Jornais e revistas são citados como os veículos de informação de menor relevância, com 30,7\% das menções entre o total de respondentes. No tocante às diferenças geracionais, percebe-se que o uso das plataformas de comunicação digital, como blogs, canais do YouTube e redes sociais, é distinto e menos incidente entre as respondentes mais velhas.

É também interessante notar que as muito jovens (entre 15 e 25 anos) dizem aprender sobre feminismo com feministas de outras gerações, uma fonte de informação menos incidente entre as mais velhas. Em sua pesquisa sobre os ativismos feministas online, por exemplo, Carolina Branco (2015) identificou nos blogs feministas canais de transmissão intergeracional do feminismo, registrando sua conexão com organizações feministas mais antigas. Isso pode explicar em parte por que as jovens feministas afirmam aprender sobre feminismo com mulheres de outras gerações. $\mathrm{O}$ dado reforça, sobretudo, aquilo que a bibliografia identifica como uma tendência mais geral de conexões e proximidades geracionais entre as feministas - a despeito das suas diferenças (Sorj, 2016; Gonçalves, 2016).

Tabela 9:Quais são as suas fontes de informação sobre o feminismo? (estimulada e múltipla)

\begin{tabular}{|l|c|c|c|c|}
\hline & $\begin{array}{c}15 \text { a } 25 \\
\text { anos }\end{array}$ & $\begin{array}{c}26 \text { a } 30 \\
\text { anos }\end{array}$ & $\begin{array}{c}31 \text { a } 43 \\
\text { anos }\end{array}$ & $\begin{array}{c}\text { Acima de } \\
44 \text { anos }\end{array}$ \\
\hline $\begin{array}{l}\text { Blogs especializados e canais do } \\
\text { YouTube }\end{array}$ & $57,9 \%$ & $51,3 \%$ & $48,6 \%$ & $36,8 \%$ \\
\hline Jornais e revistas & $23,7 \%$ & $33,3 \%$ & $35,1 \%$ & $31,6 \%$ \\
\hline Redes sociais & $84,2 \%$ & $69,2 \%$ & $78,4 \%$ & $63,2 \%$ \\
\hline $\begin{array}{l}\text { Palestras, coletivos e } \\
\text { movimentos sociais }\end{array}$ & $68,4 \%$ & $64,1 \%$ & $59,5 \%$ & $57,9 \%$ \\
\hline Livros & $63,2 \%$ & $43,6 \%$ & $67,6 \%$ & $55,3 \%$ \\
\hline Feministas de outras gerações & $60,5 \%$ & $35,9 \%$ & $48,6 \%$ & $36,8 \%$ \\
\hline Outras & $5,3 \%$ & $5,1 \%$ & $2,7 \%$ & $7,9 \%$ \\
\hline
\end{tabular}

Fonte: Elaboração própria. $\mathrm{N}=152$.

Opiniões

Em outro segmento, sondamos a opinião das manifestantes sobre oito perguntas, elaboradas na escala de Likert (com as opções "Concorda", "Concorda em parte", "Não concorda nem discorda", "Discorda em parte" e "Discorda" apresentadas em um disco para que as entrevistadas escolhessem). A lista de perguntas procurou aferir como elas se posicionam a respeito de temas considerados sensíveis dentro dos movimentos feministas, como a participação masculina, a 
questão da regulamentação da prostituição, a representação política de mulheres, a relação entre feminismo e antirracismo, as formas legítimas de protesto, a profundidade das transformações sociais necessárias à realização da igualdade de gênero, a relação entre feminismo $e$ punitivismo $e$ visões sobre gênero e diferença.

Tabela 10: Níveis de concordância sobre temas feministas

\begin{tabular}{|l|c|c|c|c|c|c|c|}
\hline & Concorda & $\begin{array}{c}\text { Concorda } \\
\text { em parte }\end{array}$ & $\begin{array}{c}\text { Não } \\
\text { concorda } \\
\text { nem discorda }\end{array}$ & $\begin{array}{c}\text { Discorda } \\
\text { em parte }\end{array}$ & Discorda & NS/NR & Total \\
\hline $\begin{array}{l}\text { Aumentar as penas contra } \\
\text { homens agressores diminuiria a } \\
\text { violência contra mulher }\end{array}$ & $32,2 \%$ & $25,7 \%$ & $1,3 \%$ & $14,5 \%$ & $25,7 \%$ & $0,7 \%$ & $100,0 \%$ \\
\hline $\begin{array}{l}\text { A causa das mulheres negras } \\
\text { deve ser prioridade na luta } \\
\text { feminista }\end{array}$ & $75,0 \%$ & $17,8 \%$ & $2,0 \%$ & $2,0 \%$ & $2,6 \%$ & $0,7 \%$ & $100,0 \%$ \\
\hline $\begin{array}{l}\text { Mulheres tendem a ser mais } \\
\text { intuitivas e generosas do que os } \\
\text { homens }\end{array}$ & $27,6 \%$ & $22,4 \%$ & $5,3 \%$ & $5,9 \%$ & $36,8 \%$ & $2,0 \%$ & $100,0 \%$ \\
\hline $\begin{array}{l}\text { Mostrar o corpo nu é uma forma } \\
\text { de empoderamento da mulher }\end{array}$ & $38,2 \%$ & $32,9 \%$ & $7,9 \%$ & $5,9 \%$ & $14,5 \%$ & $0,7 \%$ & $100,0 \%$ \\
\hline $\begin{array}{l}\text { A exploração das mulheres só } \\
\text { acabará com uma mudança } \\
\text { radical no sistema capitalista }\end{array}$ & $59,2 \%$ & $22,4 \%$ & $3,9 \%$ & $3,9 \%$ & $9,2 \%$ & $1,3 \%$ & $100,0 \%$ \\
\hline $\begin{array}{l}\text { É importante haver mais } \\
\text { mulheres eleitas } \\
\text { independentemente do partido }\end{array}$ & $63,2 \%$ & $15,1 \%$ & $2,6 \%$ & $6,6 \%$ & $11,8 \%$ & $0,7 \%$ & $100,0 \%$ \\
\hline $\begin{array}{l}\text { Os homens devem participar das } \\
\text { lutas feministas }\end{array}$ & $65,1 \%$ & $24,3 \%$ & $2,0 \%$ & $3,3 \%$ & $3,9 \%$ & $1,3 \%$ & $100,0 \%$ \\
\hline $\begin{array}{l}\text { A profissão de prostituta deve } \\
\text { ser regulamentada no Brasil }\end{array}$ & $57,9 \%$ & $17,1 \%$ & $6,6 \%$ & $2,0 \%$ & $7,9 \%$ & $8,6 \%$ & $100,0 \%$ \\
\hline
\end{tabular}

Fonte: Elaboração própria. $\mathrm{N}=152$.

Em algumas questões, as respostas foram relativamente similares entre os grupos de idade. São elas: "aumentar as penas contra homens agressores diminuiria a violência contra a mulher", "a exploração das mulheres só acabará com uma mudança radical no sistema capitalista" e "é importante haver mais mulheres eleitas independentemente do partido" (ver anexo1, com detalhamento por idade). Algumas das questões que dividiram as respondentes dialogam diretamente com a demarcação de fronteiras, identidade e repertórios de protesto, algo que se tende a atribuir aos novos feminismos ou feminismos "de terceira onda" (Budgeon, 2011). A polarização verificada foi, de modo geral, entre as mais jovens (15 a 25 anos) e as mais velhas (mais de 44 anos). Perguntadas, por exemplo, se "mostrar o corpo nu é uma forma de empoderamento da mulher", apenas $8 \%$ das mais jovens discordaram ou discordaram em parte. O índice de rejeição a esse repertório foi de $34 \%$ entre as mais velhas.

Enquanto 53\% das respondentes mais novas (15 a 25 anos) discordaram da afirmação "as mulheres tendem a ser mais intuitivas e generosas que os homens", apenas $18 \%$ das mais velhas, acima de 44 anos, o fizeram. Pesquisas qualitativas podem contribuir para elucidar melhor essas diferenças, mas temos como hipótese que as mais jovens tendem a rechaçar determinadas representações da mulher que as associam a características essenciais como a emoção e o cuidado.

A afirmação "os homens devem participar das lutas feministas" também produziu discordâncias: enquanto as mais jovens dividiram-se entre concordar $(32 \%)$ e concordar em parte $(45 \%)$, as mais velhas concordaram $(89 \%)$ sem ressalvas e somente $8 \%$ concordaram em parte. Como vimos anteriormente, as militantes mais velhas que foram entrevistadas participam com mais frequência de movimentos sociais, partidos e sindicatos mistos. Isso possivelmente influencia sua opinião quanto à parceria com homens. Além disso, o próprio ciclo de vida - casamento, maternidade etc. - de algumas dessas mulheres pode estar relacionado a tal posição. 
Um bloco específico de perguntas procurou tocar em questões que têm ganhado grande visibilidade nas redes sociais e no ativismo feminista virtual. Um fato que chamou atenção foi a diferença sensível entre grupos de idade a respeito da relação entre feminismo $e$ antirracismo. Quando perguntamos se as respondentes concordam ou discordam que a causa das mulheres negras deve ser prioridade no feminismo, a concordância incondicional foi mais elevada entre as mulheres acima de 44 anos (92,1\% concordaram e 5,3\% concordaram em parte) do que entre aquelas que têm entre 15 e 25 anos (65,8\% concordaram e 28,9\% concordaram em parte).

$\mathrm{O}$ fenômeno da diferença geracional se repetiu com relação à questão da prostituição: as opiniões variaram por geração, seguindo uma espécie de continuum entre as faixas de idade. A objeção à regulamentação da prostituição foi significativamente mais elevada entre as militantes mais jovens: a concordância total entre as mais novas foi de $47 \%$ e entre as mais velhas foi de $71 \%$. A diferença de opinião entre essas faixas etárias pode estar associada a debates políticos característicos da geração feminista mais recente a respeito do lugar de gênero, raça, classe $e$ sexualidade como fatores explicativos das desigualdades e com pontos de apoio para a luta política.

O campo político do feminismo da nova geração tem sido tensionado por correntes distintas. Grosso modo, há uma oposição entre as perspectivas da interseccionalidade, isto é, da articulação do feminismo com outras lutas e grupos, e o "feminismo radical", que advoga pela centralidade da categoria "mulher" sob outros eixos na compreensão das desigualdades e das relações de poder. Essa corrente tende, por exemplo, a defender a abolição da prostituição (Branco, 2015).

No entanto, há uma tendência mais ampla de oposições bastante tensas nos jovens feminismos a respeito do debate sobre a prostituição (Gonçalves, 2016). Talvez a maior centralidade da sexualidade como catalisadora de alguns desses "jovens feminismos" contribua para colocar em relevo o debate sobre a prostituição, visto que ele envolve diretamente questões de sexualidade. Nosso estudo descritivo não permite fazer inferências mais robustas a esse respeito, mas sugere que há caminhos a serem aprofundados por outras pesquisas.

\section{Considerações finais}

A título de conclusão, destacamos agora alguns achados mais significativos do nosso estudo. Primeiro, verificamos mudanças consideráveis na composição social, racial, etária e de classe social das feministas. Identificamos também mudanças no tocante à sexualidade: além de ganhar mais expressões, ela parece ter assumido mais importância. As feministas mais jovens demonstram mais atenção às sexualidades $e$ às identidades de gênero do que as mais velhas, mostrando mais domínio sobre o léxico acadêmico e ativista contemporâneo sobre gênero. Tudo isso, somado à alta escolaridade das entrevistadas, sinaliza que o processo de expansão e democratização do Ensino Superior ocorridas nos anos 2000 foi muito importante para a formação de uma nova geração de feministas, proporcionando uma estrutura e um espaço de socialização e construção de redes. Nesse mesmo sentido, as redes virtuais também foram identificadas como um importante canal de fortalecimento das redes feministas.

A ampla maioria das entrevistadas se posicionou ideologicamente à esquerda, independentemente da faixa etária. Entretanto, a geração mais velha de feministas está mais envolvida com partidos, sindicatos e movimentos sociais, bem como mais ligada a pautas políticas associadas à conjuntura. As mais jovens, por sua vez, aparecem como as únicas a chamar atenção para temas como sexualidade e liberdade de orientação sexual. Tudo isso pode ser reflexo da própria influência do ciclo de vida dessas mulheres, mas, apesar de algumas diferenças sensíveis, nossos dados parecem se alinhar com pesquisas qualitativas que mostram que as pautas feministas centrais - a questão da violência, a igualdade no mercado de trabalho e a descriminalização do aborto - não mudaram substancialmente.

A relação com as plataformas de informação e comunicação digital também se diferencia por idade, assim como as opiniões sobre métodos e estratégias de protesto. A participação de homens nos movimentos feministas dividiu sensivelmente as opiniões, assim como o foco na causa das mulheres negras e a regulamentação da prostituição. Nos dados globais, há uma aceitação elevada sem ressalvas $(75,2 \%)$ da causa das mulheres negras como prioridade no feminismo. No entanto, essa aceitação é mais alta entre as mais velhas do que entre as mais jovens - talvez uma expressão 
das próprias tensões que correm dentro de um campo feminista, cada vez mais diverso e plural. Quanto à prostituição, a aceitação da regulamentação sem restrições é muito maior entre as mais velhas $(71,1 \%)$ do que entre as mais novas $(47,4 \%)$. Ambos os casos requerem mais pesquisa $e$ investigação. Por ora, arriscamos dizer que, ao crescer e se tornar um movimento de grande porte, o feminismo vê uma multiplicação de visões divergentes no seu interior.

\section{Referências bibliográficas}

ADRIÃO, Karla e MELLO, Ricardo. As Jovens feministas: sujeitos políticos que entrelaçam questões de gênero e geração? Artigo apresentado no XV Encontro Nacional da Abrapso, realizado em Maceió, 2009. .

ALVAREZ, Sonia E. Para além da sociedade civil: reflexões sobre o campo feminista. cadernos pagu (43), Campinas, Núcleo de Estudos de Gênero-Pagu/Unicamp, 2014, pp.13-56.

BORBA, Felipe. Parada do Orgulho LGBT: a voz e o voto. Insight Inteligência. jan/fev/mar, 2017, pp.80-88.

BLAY, Eva. 8 de Março: conquistas e controvérsias. Revista Estudos Feministas [online], v.9, n.2, 2001, pp.601-607.

BOURDIEU, Pierre. A "juventude" é apenas uma palavra. Questóes de sociologia. Rio de Janeiro, Marco Zero, 1983, pp.112-121.

BRANCO, Carolina de Castro Ferreira. Feminismos web: linhas de ação e maneiras de atuação no debate feminista contemporâneo. cadernos pagu (44), Campinas, Núcleo de Estudos de Gênero-Pagu/Unicamp 2015, pp.199-228.

BUARQUE DE HOLLANDA, Heloísa (org.). Explosão feminista: arte, cultura, política e universidade. São Paulo, Companhia das Letras. 2018.

BUDGEON, Shelley. Third Wave Feminism and the Politics of Gender in Late Modernity. New York, Palgrave McMillan. 2011.

CORREAA, Mariza. Do feminismo aos estudos de gênero no Brasil: um exemplo pessoal. cadernos pagu (16), Campinas, Núcleo de Estudos de Gênero-Pagu/Unicamp, 2001, pp.13-30.

DATAFOLHA Instituto de Pesquisas. Eleições municipais 2016, 2016. [http://media.folha.uol.com.br/datafolha/2016/10/c33a8eac0b4f019c94af2dcade08b2f3b577a01b.pdf acesso em: 19 fev 2020].

DELLA PORTA, Donatella. Repertoires of contention. In: SNOW, D. A. e DELLA PORTA, Donatella (ed.). The Wiley-Blackwell Encyclopedia of Social and Political Movements. Malden, Blackell, 2013.

FOWLER JR., Floyd. Pesquisa de levantamento. Porto Alegre, Penso, 2011.

GARCÍA MUÑOZ, Soledad. Género y derechos humanos de las mujeres: estándares conceptuales y normativos en clave de derecho internacional. In: PARCERO, Juan A.; CRUZ \& VÁZQUEZ, Rodolfo (coord.). Derechos de las Mujeres en el Derecho Internacional. Coyoacán, Fontamara, 2010, pp.47-84.

GONÇALVES, Eliane. Renovar, inovar, rejuvenescer: processos de transmissão, formação e permanência no feminismo brasileiro entre 1980-2010. Revista Brasileira de Sociologia, v.4, n.7, jan/jun. 2016, pp.341370.

GONÇALVES, Eliane; PINTO, Joana. Reflexões e problemas da "transmissão" intergeracional no feminismo brasileiro. cadernos pagu (36), Campinas, Núcleo de Estudos de Gênero-Pagu/Unicamp, 2011, pp.25-46.

GONZÁLEZ, Ana Isabel Álvarez. As origens e a comemoração do dia internacional das mulheres. São Paulo, Editora Expressão Popular. 2010.

GOMES, Carla; SORJ, Bila. Corpo, geração e identidade: a Marcha das Vadias no Brasil. Revista Sociedade e Estado, v. 29, n. 2, 2014, pp.433-447.

JASPER, James. Protest: a Cultural Introduction to Social Movements. Cambridge, Polity Press. 2014.

JOHNSON, Janeth Buttolph B.; REYNOLD, Henry. T.; MYCOFF, Jason D.. Political Science Research Methods. Washington, CQ Press, 2015. 
LIMA, Márcia. Introdução aos métodos quantitativos em ciências sociais. In: ABDAL, Alexandre; OLIVEIRA, Maria Carolina Vasconcelos; GHEZZI, Daniela Ribas. Métodos de Pesquisa em Ciências Sociais: Bloco Quantitativo. São Paulo, SESC / CEBRAP, 2016, pp.10-31.

MELO, Hildete P.; THOMÉ, Débora. Mulheres e Poder: histórias, ideias e indicadores. Rio de Janeiro, FGV Editora, 2018.

NAME, Leonardo; ZANETTI, Julia. Meu corpo, minhas redes: a Marcha das Vadias do Rio de Janeiro. In: Encontro Nacional da Associação Nacional de Pós-Graduação e Pesquisa em Planejamento Urbano e Regional, 15, 2013. Anais... Recife, ANPUR, 2013.

O ESTADO DE S. PAULO. Mulheres vão às ruas em 16 estados, 2017. [http://brasil.estadao.com.br/noticias/geral,mulheres-vao-as-ruas-em-16-estados,70001692435 - acesso em: 7 ago 2018].

SANCHEZ, Beatriz Rodrigues. As interações entre os movimentos feministas e o Congresso Nacional brasileiro: uma proposta de análise. In: VII Seminário Discente da Pós-Graduação em Ciência Política da USP. 8 a 12 de maio. 2017.

SCOTT, Joan. Gênero: uma categoria útil de análise histórica. Educação \& Realidade, v. 20, n. 2, Porto Alegre, 1995.

SORJ, Bila. Do "pessoal é político" para o "político é pessoal"? Novas tendências no feminismo no Brasil. In: XXXIV International Congress of the Latin American Studies Association, NY, 2016.

WALGRAVE, Stefaan; VERHULST, Joris. Selection and response bias in protest surveys. Mobilization: An International Journal, v. 16, n. 2, 2011, pp.203-222.

ZANELLA, Andréa et al. Jovens, juventude e políticas públicas: Produção acadêmica em periódicos científicos brasileiros (2002 a 2011). Estudos de Psicologia, 18(2), abril-junho2013, pp.27-333. 
Anexo 1: Níveis de concordância sobre temas feministas e idade

\begin{tabular}{|c|c|c|c|c|c|c|c|}
\hline $\begin{array}{c}\text { Aumentar as penas } \\
\text { contra homens } \\
\text { agressores diminuiria a } \\
\text { violência contra a } \\
\text { mulher }\end{array}$ & Concorda & $\begin{array}{l}\text { Concorda } \\
\text { em parte }\end{array}$ & $\begin{array}{c}\text { Não } \\
\text { concorda } \\
\text { nem discorda }\end{array}$ & $\begin{array}{l}\text { Discorda } \\
\text { em parte }\end{array}$ & Discorda & NS/NR & Total \\
\hline 15 a 25 anos & $34,2 \%$ & $28,9 \%$ & $2,6 \%$ & $7,9 \%$ & $23,7 \%$ & $2,6 \%$ & $100,0 \%$ \\
\hline 26 a 30 anos & $35,9 \%$ & $20,5 \%$ & $0,0 \%$ & $15,4 \%$ & $28,2 \%$ & $0,0 \%$ & $100,0 \%$ \\
\hline 31 a 43 anos & $15,8 \%$ & $28,9 \%$ & $2,6 \%$ & $21,1 \%$ & $31,6 \%$ & $0,0 \%$ & $100,0 \%$ \\
\hline Acima de 44 anos & $42,1 \%$ & $23,7 \%$ & $0,0 \%$ & $15,8 \%$ & $18,4 \%$ & $0,0 \%$ & $100,0 \%$ \\
\hline $\begin{array}{l}\text { A causa das mulheres } \\
\text { negras deve ser } \\
\text { prioridade na luta } \\
\text { feminista }\end{array}$ & Concorda & $\begin{array}{l}\text { Concorda } \\
\text { em parte }\end{array}$ & $\begin{array}{c}\text { Não } \\
\text { concorda } \\
\text { nem discorda }\end{array}$ & $\begin{array}{l}\text { Discorda } \\
\text { em parte }\end{array}$ & Discorda & NS/NR & Total \\
\hline 15 a 25 anos & $65,8 \%$ & $28,9 \%$ & $2,6 \%$ & $2,6 \%$ & $0,0 \%$ & $0,0 \%$ & $100,0 \%$ \\
\hline 26 a 30 anos & $66,7 \%$ & $20,5 \%$ & $0,0 \%$ & $5,1 \%$ & $5,1 \%$ & $2,6 \%$ & $100,0 \%$ \\
\hline 31 a 43 anos & $76,3 \%$ & $15,8 \%$ & $2,6 \%$ & $0,0 \%$ & $5,3 \%$ & $0,0 \%$ & $100,0 \%$ \\
\hline Acima de 44 anos & $92,1 \%$ & $5,3 \%$ & $2,6 \%$ & $0,0 \%$ & $0,0 \%$ & $0,0 \%$ & $100,0 \%$ \\
\hline $\begin{array}{c}\text { Mulheres tendem a ser } \\
\text { mais intuitivas e } \\
\text { generosas do que os } \\
\text { homens }\end{array}$ & Concorda & $\begin{array}{l}\text { Concorda } \\
\text { em parte }\end{array}$ & $\begin{array}{c}\text { Não } \\
\text { concorda } \\
\text { nem discorda }\end{array}$ & $\begin{array}{l}\text { Discorda } \\
\text { em parte }\end{array}$ & Discorda & NS/NR & Total \\
\hline 15 a 25 anos & $10,5 \%$ & $31,6 \%$ & $2,6 \%$ & $0,0 \%$ & $52,6 \%$ & $2,6 \%$ & $100,0 \%$ \\
\hline 26 a 30 anos & $20,5 \%$ & $20,5 \%$ & $7,7 \%$ & $12,8 \%$ & $38,5 \%$ & $0,0 \%$ & $100,0 \%$ \\
\hline 31 a 43 anos & $23,7 \%$ & $18,4 \%$ & $7,9 \%$ & $2,6 \%$ & $44,7 \%$ & $2,6 \%$ & $100,0 \%$ \\
\hline Acima de 44 anos & $55,3 \%$ & $21,1 \%$ & $2,6 \%$ & $7,9 \%$ & $10,5 \%$ & $2,6 \%$ & $100,0 \%$ \\
\hline $\begin{array}{c}\text { Mostrar o corpo nu é } \\
\text { uma forma de } \\
\text { empoderamento da } \\
\text { mulher }\end{array}$ & Concorda & $\begin{array}{l}\text { Concorda } \\
\text { em parte }\end{array}$ & $\begin{array}{c}\text { Não } \\
\text { concorda } \\
\text { nem discorda }\end{array}$ & $\begin{array}{l}\text { Discorda } \\
\text { em parte }\end{array}$ & Discorda & NS/NR & Total \\
\hline 15 a 25 anos & $47,4 \%$ & $34,2 \%$ & $10,5 \%$ & $2,6 \%$ & $5,3 \%$ & $0,0 \%$ & $100,0 \%$ \\
\hline 26 a 30 anos & $33,3 \%$ & $46,2 \%$ & $5,1 \%$ & $2,6 \%$ & $12,8 \%$ & $0,0 \%$ & $100,0 \%$ \\
\hline 31 a 43 anos & $36,8 \%$ & $26,3 \%$ & $10,5 \%$ & $7,9 \%$ & $15,8 \%$ & $2,6 \%$ & $100,0 \%$ \\
\hline Acima de 44 anos & $36,8 \%$ & $23,7 \%$ & $5,3 \%$ & $10,5 \%$ & $23,7 \%$ & $0,0 \%$ & $100,0 \%$ \\
\hline $\begin{array}{l}\text { A exploração das } \\
\text { mulheres só acabará } \\
\text { com uma mudança } \\
\text { radical no sistema } \\
\text { capitalista }\end{array}$ & Concorda & $\begin{array}{l}\text { Concorda } \\
\text { em parte }\end{array}$ & $\begin{array}{c}\text { Não } \\
\text { concorda } \\
\text { nem discorda }\end{array}$ & $\begin{array}{l}\text { Discorda } \\
\text { em parte }\end{array}$ & Discorda & NS/NR & Total \\
\hline 15 a 25 anos & $63,2 \%$ & $23,7 \%$ & $5,3 \%$ & $5,3 \%$ & $2,6 \%$ & $0,0 \%$ & $100,0 \%$ \\
\hline 26 a 30 anos & $51,3 \%$ & $30,8 \%$ & $2,6 \%$ & $5,1 \%$ & $7,7 \%$ & $2,6 \%$ & $100,0 \%$ \\
\hline
\end{tabular}




\begin{tabular}{|c|c|c|c|c|c|c|c|}
\hline 31 a 43 anos & $71,1 \%$ & $10,5 \%$ & $5,3 \%$ & $0,0 \%$ & $13,2 \%$ & $0,0 \%$ & $100,0 \%$ \\
\hline Acima de 44 anos & $52,6 \%$ & $23,7 \%$ & $2,6 \%$ & $5,3 \%$ & $13,2 \%$ & $2,6 \%$ & $100,0 \%$ \\
\hline $\begin{array}{c}\text { É importante haver } \\
\text { mais mulheres eleitas } \\
\text { independentemente do } \\
\text { partido }\end{array}$ & Concorda & $\begin{array}{l}\text { Concorda } \\
\text { em parte }\end{array}$ & $\begin{array}{c}\text { Não } \\
\text { concorda } \\
\text { nem discorda }\end{array}$ & $\begin{array}{l}\text { Discorda } \\
\text { em parte }\end{array}$ & Discorda & NS/NR & Total \\
\hline 15 a 25 anos & $65,8 \%$ & $15,8 \%$ & $2,6 \%$ & $5,3 \%$ & $10,5 \%$ & $0,0 \%$ & $100,0 \%$ \\
\hline 26 a 30 anos & $61,5 \%$ & $12,8 \%$ & $2,6 \%$ & $12,8 \%$ & $7,7 \%$ & $2,6 \%$ & $100,0 \%$ \\
\hline 31 a 43 anos & $50,0 \%$ & $21,1 \%$ & $5,3 \%$ & $7,9 \%$ & $15,8 \%$ & $0,0 \%$ & $100,0 \%$ \\
\hline Acima de 44 anos & $73,7 \%$ & $10,5 \%$ & $0,0 \%$ & $2,6 \%$ & $13,2 \%$ & $0,0 \%$ & $100,0 \%$ \\
\hline $\begin{array}{l}\text { Os homens devem } \\
\text { participar das lutas } \\
\text { feministas }\end{array}$ & Concorda & $\begin{array}{l}\text { Concorda } \\
\text { em parte }\end{array}$ & $\begin{array}{c}\text { Não } \\
\text { concorda } \\
\text { nem discorda }\end{array}$ & $\begin{array}{l}\text { Discorda } \\
\text { em parte }\end{array}$ & Discorda & NS/NR & Total \\
\hline 15 a 25 anos & $31,6 \%$ & $44,7 \%$ & $5,3 \%$ & $10,5 \%$ & $7,9 \%$ & $0,0 \%$ & $100,0 \%$ \\
\hline 26 a 30 anos & $71,8 \%$ & $23,1 \%$ & $0,0 \%$ & $0,0 \%$ & $2,6 \%$ & $2,6 \%$ & $100,0 \%$ \\
\hline 31 a 43 anos & $68,4 \%$ & $21,1 \%$ & $0,0 \%$ & $2,6 \%$ & $5,3 \%$ & $2,6 \%$ & $100,0 \%$ \\
\hline Acima de 44 anos & $89,5 \%$ & $7,9 \%$ & $2,6 \%$ & $0,0 \%$ & $0,0 \%$ & $0,0 \%$ & $100,0 \%$ \\
\hline $\begin{array}{l}\text { A profissão de } \\
\text { prostituta deve ser } \\
\text { regulamentada no } \\
\text { Brasil }\end{array}$ & Concorda & $\begin{array}{l}\text { Concorda } \\
\text { em parte }\end{array}$ & $\begin{array}{c}\text { Não } \\
\text { concorda } \\
\text { nem discorda }\end{array}$ & $\begin{array}{l}\text { Discorda } \\
\text { em parte }\end{array}$ & Discorda & $\mathrm{NS} / \mathrm{NR}$ & Total \\
\hline 15 a 25 anos & $47,4 \%$ & $21,1 \%$ & $13,2 \%$ & $2,6 \%$ & $10,5 \%$ & $5,3 \%$ & $100,0 \%$ \\
\hline 26 a 30 anos & $59,0 \%$ & $20,5 \%$ & $2,6 \%$ & $0,0 \%$ & $7,7 \%$ & $10,3 \%$ & $100,0 \%$ \\
\hline 31 a 43 anos & $55,3 \%$ & $15,8 \%$ & $5,3 \%$ & $2,6 \%$ & $10,5 \%$ & $10,5 \%$ & $100,0 \%$ \\
\hline Acima de 44 anos & $71,1 \%$ & $10,5 \%$ & $5,3 \%$ & $2,6 \%$ & $2,6 \%$ & $7,9 \%$ & $100,0 \%$ \\
\hline
\end{tabular}

